\title{
THE EFFECT OF EXERCISE SPECIFIC TO USE DESIGNER (QUALITY RESPONSE) DEVICE TO DEVELOP THE SPEED AND ACCURACY OF THE RECEPTION AND PASSING SKILLS OF FOOTBALL PLAYERS IN AGES (14 YEARS)
}

Haider Rahim Ghawi Asadi, Prof.Dr. Sabah Qasim Khalaf

University of Baghdad / College of Physical Education and Sports Sciences

DOI: $10.37648 / \mathrm{ijrssh.v10i01.049}$

Received:18 ${ }^{\text {th }}$ November 2019; Accepted:20 $0^{\text {th }}$ December, 2019; Published:19 ${ }^{\text {th }}$ January, 2020

\begin{abstract}
:
The world has recently witnessed remarkable progress in all fields and different sciences, and the science of athletic training is one of these sciences that has witnessed great development as it is an inevitable result of scientific progress that relied on the results of research and studies conducted in this field, and the wheel of progress did not stop, but studies are still continuing For the purpose of obtaining the best curricula and training methods that achieve high levels of performance development and he researcher used the experimental approach to its relevance to the nature of the phenomenon (the problem) and

The original community is represented by the players of the National Centers for Sports Talent for Football Category (2005), ages (14 years), and they are (215) players throughout Iraq and The most important search results - The exercises for using the designed QUALITY RESPONSE have effective and positive impact on developing the speed and accuracy of reception and passing skill performance.
\end{abstract}

\section{INTRODUCTION}

The world has recently witnessed remarkable progress in all fields and different sciences, and the science of athletic training is one of these sciences that has witnessed great development as it is an inevitable result of scientific progress that relied on the results of research and studies conducted in this field, and the wheel of progress did not stop, but studies are still continuing For the purpose of obtaining the best curricula and training methods that achieve high levels of performance development.

As the football game is one of the difference games with a competitive nature, it achieves a high level of excitement, suspense, and the pleasure of performance and achieving goals, as it is characterized by charming 
technical touches, in addition to the presence of competing players and clubs that result in the proliferation of players and the mechanism of their position in the playing field, each These facts made it a game that appeals to the mind and heart, and this may explain part of the huge public passion.

The football game requires its practitioners to have special specifications that enable them to perform various skills and moves during play, because the modern playing method is characterized by a speed character in the implementation of skills, which requires that the player has the talent and ability to implement these skills and for the work to be codified in a correct scientific manner planned It starts from the age stages, which are a basic basis for perfecting it well and correctly to reach the degree of automation (mechanism) in implementing the performance.

The interest in training age groups has taken a large part of those involved in programmed planning, and science is the most important pillar of how to deal with these ages as the basis and important tributary of clubs and national teams in the future, as the emerging player has privacy in training and a successful coach is the one who can motivate and extract everything that The young person has capabilities and capabilities to help him achieve the goal, either through the use of modern training curricula or by using advanced training methods, devices and tools are among these methods used and important in the stages of preparing the emerging player what distinguishes them as seeing I am aware of the stages of growth that the young person is going through and work within his physical and skill capabilities, and help increase suspense and excitement, increase competition and get players out of the monotony and boredom that accompanies the training of the emerging player in other methods used, hence the importance of the study in how to develop characteristics affecting performance (reception skill) Composite scrolling), by preparing exercises using a modern advanced electronic training (designer) device that contributes to achieving the goals of the training process on the one hand and the development of players and the football game on the other.

:Research problem

Each of the sports games has special skills that are considered one of the main factors for excellence and greatly help in achieving achievement. It is through the field researcher's experience that he is a former international player and coach at the present time and holds training certificates from the Asian Federation in the field of soccer training and after doing a lot of analysis Team matches and some of the local league matches for the Sunni age stages, the researcher found that there is a weakness in (technology) players of the age groups, especially with regard to the ability to control and control the ball and hold it for long periods due to their low skill capabilities, especially the vehicle among them (the Receiving and passing, rolling and passing, receiving and rolling and scoring) and other compounding skills, so the researcher decided to prepare special exercises using the QUALITY RESPONSE device, which works to develop the speed and accuracy of performing some complex skills affecting performance in a manner consistent with the difficulties of implementation during play, to find Real solutions to the study problem.

:Research Scorer

- Designing an electronic device (QUALITY RESPONSE) to develop the speed and accuracy of the combined reception and passing skill performance of football players ages (14) years.

- Prepare special exercises using the QUALITY RESPONSE device that is designed to develop the speed and accuracy of the combined reception and passing skill performance of the members of the research sample.

- Learn about the effect of exercises on using the QUALITY RESPONSE device designed to develop the speed and accuracy of reception and passing skill performance among the members of the research sample.

:Research hypotheses

QU The designer QUALITY RESPONSE has a positive influence on developing the speed and accuracy of the reception and passing skill performance of football players with ages (14) years.

- There are statistically significant differences between the pre and post tests of the experimental and control groups in the speed and accuracy of the performance of the combined reception and passing skill of the individuals in the research sample.

- There are statistically significant differences in the results of the post-tests between the two groups (experimental and controlling) in the speed and accuracy of the performance of the receiving and 
passing skill complex among the members of the research sample.

: Research fields

:The Human Domain

Players of the National Centers for Sports Talent Football (2005) Age (14 years).

:Time domain

For the period from (6/7/2019) to (16/10/2019).

:Spatial domain

The National Center for Sports Talent Care, affiliated to the Ministry of Youth and Sports, in the People's Stadium Complex.

\section{MATERIALS AND METHODS:}

\section{Research Methodology:}

Table (1)

Demo design for two groups (experimental and control)

\begin{tabular}{|c|c|c|c|c|c|c|}
\hline \multicolumn{5}{|l|}{ Steps } & \multirow{2}{*}{\multicolumn{2}{|c|}{ Groups }} \\
\hline Fifth & Fourth & The third & the second & $\begin{array}{l}\text { The } \\
\text { first }\end{array}$ & & \\
\hline \multirow{2}{*}{$\begin{array}{l}\text { The difference } \\
\text { between } \\
\text { posttest tests } \\
\text { For two groups }\end{array}$} & $\begin{array}{l}\text { The difference } \\
\text { between pre and } \\
\text { post test }\end{array}$ & $\begin{array}{l}\text { Test } \\
\text { After }\end{array}$ & $\begin{array}{l}\text { Researcher } \\
\text { treatment } \\
\text { variable) }\end{array}$ & $\begin{array}{l}\text { Test } \\
\text { before }\end{array}$ & $\begin{array}{l}\text { Experiment } \\
\text { al group }\end{array}$ & \multirow[b]{2}{*}{ the sample } \\
\hline & $\begin{array}{l}\text { The difference } \\
\text { between pre and } \\
\text { post test }\end{array}$ & $\begin{array}{l}\text { Test } \\
\text { After }\end{array}$ & Coaching / Coaching & $\begin{array}{l}\text { Test } \\
\text { before }\end{array}$ & $\begin{array}{l}\text { Control } \\
\text { group }\end{array}$ & \\
\hline
\end{tabular}

\section{Search community and sample:}

The original community is represented by the players of the National Centers for Sports Talent for Football Category (2005), ages (14 years), and they are (215) players throughout Iraq, see Table (2)

Table (2)

Describes the description of the parent search community

\begin{tabular}{|l|l|l|l|}
\hline percentage \% & Number of Players & Center & sequence \\
\hline $\mathbf{8 . 8 8 \%}$ & $\mathbf{2 0}$ & Baghdad / Al-Shaab Stadium & $\mathbf{1}$ \\
\hline $\mathbf{8 . 8 8 \%}$ & $\mathbf{2 0}$ & Baghdad / Al-Zafaraniyah & $\mathbf{2}$ \\
\hline $\mathbf{8 . 8 8 \%}$ & $\mathbf{2 0}$ & Baghdad / Ghazaliya & $\mathbf{3}$ \\
\hline $\mathbf{6 . 6 6 \%}$ & $\mathbf{1 5}$ & Diyala & $\mathbf{4}$ \\
\hline
\end{tabular}




\begin{tabular}{|l|l|l|l|}
\hline $6.66 \%$ & 15 & Samawah (Muthanna) & 5 \\
\hline $6.66 \%$ & 15 & Karbala & 6 \\
\hline $6.66 \%$ & 15 & Najaf & 7 \\
\hline $6.66 \%$ & 15 & Diwaniya & $\mathbf{8}$ \\
\hline $13.33 \%$ & 30 & Kirkuk & $\mathbf{9}$ \\
\hline $6.66 \%$ & 15 & Babylon (Hilla) & 10 \\
\hline $6.66 \%$ & 15 & Basra & 11 \\
\hline $6.66 \%$ & 15 & Salahuddin & 12 \\
\hline $6.66 \%$ & 15 & Anbar & 13 \\
\hline $100 \%$ & 225 & Total & \\
\hline
\end{tabular}

Description of the research community:

The researcher intends to choose the research community represented by the centers of the Baghdad governorate in the willful manner, for the following reasons:

- The researcher's proximity to the training grounds for the centers, as he is from Baghdad Governorate.

- The centers' commitment to the dates of the exercises, therefore, they are considered ideal for conducting the experiment.

- Provides all tools and means that can contribute to the success of the experiment.

- The possibility of obtaining the sample due to the cooperation of the centers departments and trainers with the researcher.

:Description of the research sample

As for the research sample, which is "the part that represents the community of origin or the model that the researcher conducts the overall focus of his work on" it was chosen randomly (the lottery) from among the research community that includes three centers in the Baghdad governorate, which was represented by the players of the Baghdad Center ( AlShaab Stadium), as the sample was divided into two equal groups (experimental and controlling) in a random manner (the lottery), as each player was given a special number from (1-20), and by using the lottery they were divided into two groups (individually, doubles) each group (10) Players made up (8.88\%) of the original research community.

:Parity of the sample

In order for the division to be unbiased for one of the two groups and to maintain the scientific objectivity and to ensure one starting point at the beginning of the research and to avoid the factors that may affect the results of the experiment the researcher intentionally found the equivalence between the two research groups and table (3) shows the equivalence of the sample in the results of the tribal tests of the two groups (experimental and control). 
Table (3)

Equivalence of the sample in the pre-test results of the two groups (experimental and control)

\begin{tabular}{|c|c|c|c|c|c|c|c|}
\hline \multirow{2}{*}{$\begin{array}{l}\text { Indication of } \\
\text { differences }\end{array}$} & \multirow[t]{2}{*}{ sig } & \multicolumn{2}{|c|}{ Control group } & \multicolumn{2}{|c|}{ Experimental group } & \multirow{2}{*}{$\begin{array}{l}\text { measruing } \\
\text { unit }\end{array}$} & \multirow{2}{*}{ Processors } \\
\hline & & $\begin{array}{l}\text { standard } \\
\text { deviation }\end{array}$ & $\begin{array}{l}\text { Arithmetic } \\
\text { mean }\end{array}$ & $\begin{array}{l}\text { standard } \\
\text { deviation }\end{array}$ & $\begin{array}{l}\text { Arithmetic } \\
\text { mean }\end{array}$ & & \\
\hline Not significant & 0.350 & 0.041 & 0.473 & 0.0382 & 0.456 & $\begin{array}{l}\text { Minutes / } \\
\text { second }\end{array}$ & reception and pass \\
\hline
\end{tabular}

(*)Degree of Freedom $=18$ below the 0.05 error level

Means of gathering information, tools and devices used in research:

The researcher used the following for the purpose of obtaining information and data:

: Ways to collect information

.Arab and foreign sources -

Opinions of experts and specialists (personal interviews) -

) .International Information Network (Internet -

.Tests and measurements -

.Auxiliary Work Team -(*)

Exploratory experience.-

.Data collection and dump forms $-(* *)$

Statistical means -

: Tools used in the research

) .MOLTEN type soccer balls (10 -

.TIMEX stopwatch made (China), count (2) -

.Suppression of number (15) -

.Cons (10) cone -

.Stairs (3) -

) .MOLTEN type whistles (2 -

.A soccer goal of different sizes -

.A leather tape measuring 20 meters -

.Colorful duct tape (three colors) -

Pigments.-

) .Medical scale (1 -

:The designer used in the research

- Designed electronic device (QUALITY RESPONSE), number (1), number of panels (12).

) .POLAR H10 number (10 - (***) (

).A computer type (ASUS) made (China) number (1 -

.A computer type (hp), made (china), number (1) -

.Apple iPad tablet (1) -

- Canon cameras, made (China), count (2). 


\section{FIELD RESEARCH PROCEDURES:}

\section{QUALITY RESPONSE:}

The quality response device was designed and manufactured by the researcher after presenting the idea of the project to the members of the Seminar Committee and the Scientific Committee and to the supervisor, as their valuable observations were taken, which contributed greatly to the apparatus's final appearance, the purpose of designing and manufacturing this device is for Provide assistance to coaches and players to train and develop basic and vehicle skills in a manner similar to the conditions for performing the skill in the game, as it is possible to develop the following:

)Reception skill (suppression) - passing - scoring - rolling and passing - receiving and rolling and passing - reception and scoring - reception, rolling and scoring).

device components:

The primary materials that make up the device are:

:Fulcrum base

This base was made of solid iron and it was designed in an artistic way as (welding) was not used between the parts of the base but was designed from one piece, its measurements $(50 \mathrm{~cm}$ height x $50 \mathrm{~cm}$ length x $80 \mathrm{~cm}$ width) see figure (1).

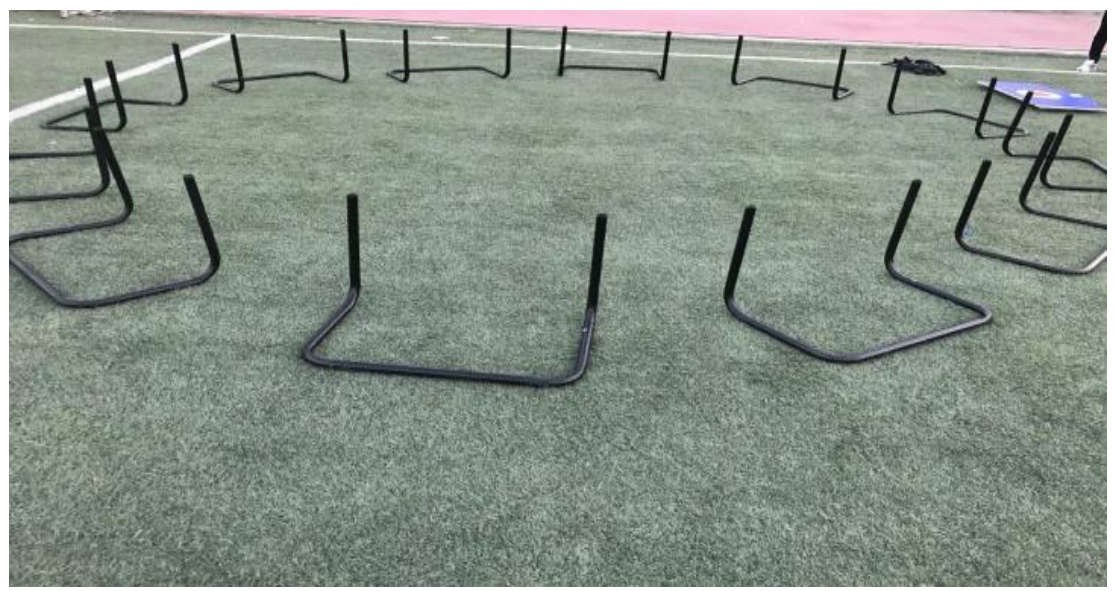

Figure (1)

:panels

The panels are made of compact synthetic wood material and this type of wood has been used to ensure the ball bounces, which helps greatly in achieving the goal for which the device was designed, its measurements are $(50) \mathrm{cm}$. Cm width and figure (2) illustrate this.

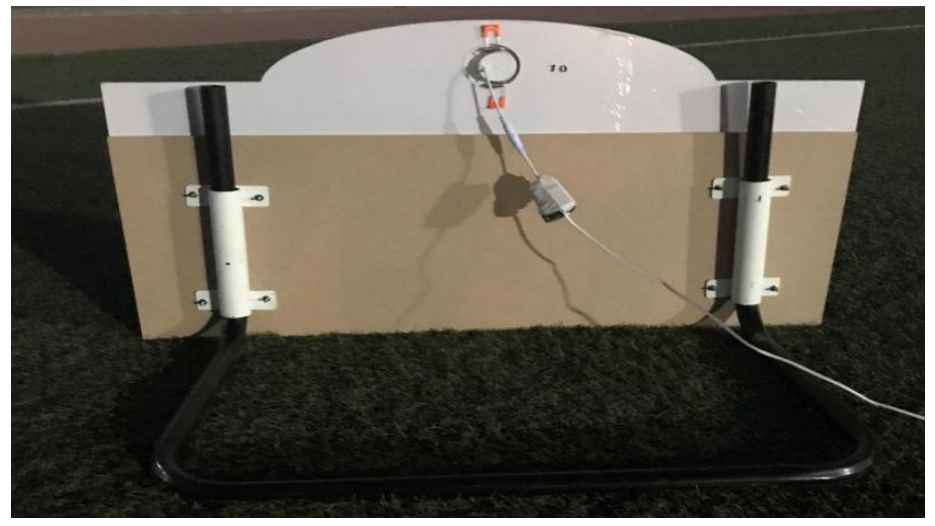

Figure (2)

Control System: 
It is an electric box made of plastic material and is considered a control center for remote control. It contains a set of buttons that are used to alert and give the visual stimulus (lights) and audio (beep) command. See Figure (3).

:Power on / off button

buttons connected to the boards were used by electrical cables to give the instructions

Audiovisual see Figure (3)

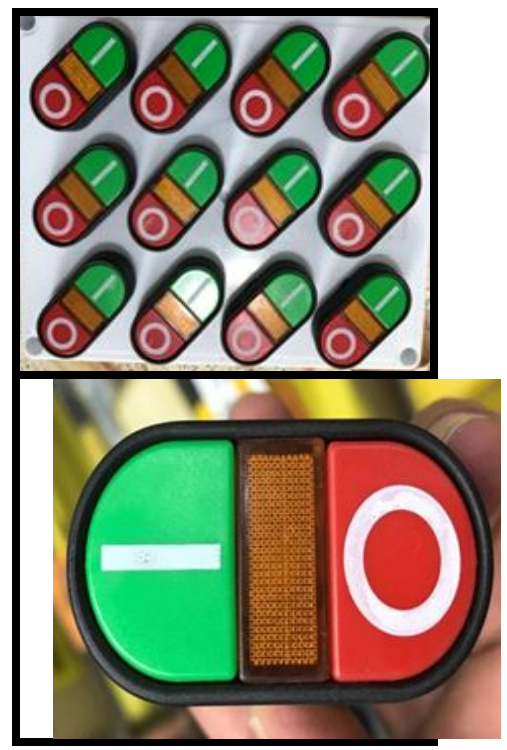

Figure (3)

:Whistle sound

beeps were used with the number of panels linked with the lamps to launch an audible alert to the player. Figure (4) illustrates this.

:LEDs

Light bulbs (white, yellow, blue, green) were used as a visual stimulator to alert players (Figure 4).

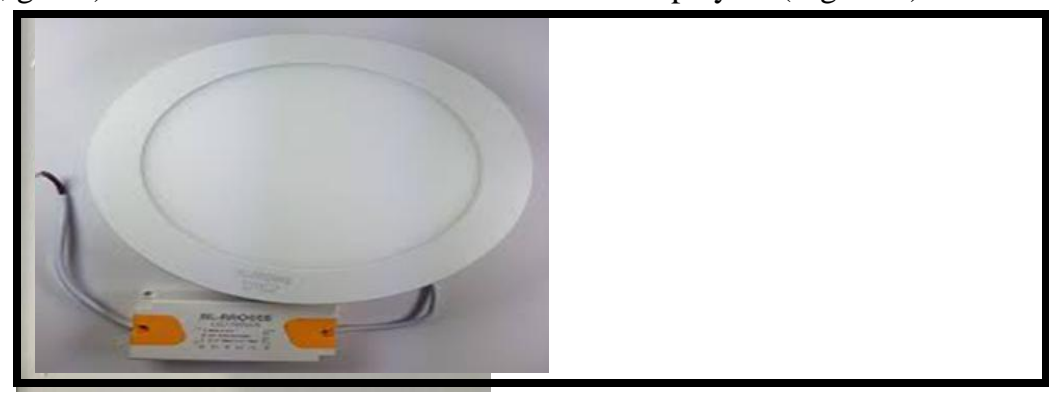

Figure (4)

How the device works:

The device is connected to the electricity by electrical wires, as one of the auxiliary staff members controls the stimuli through the control system by pressing the buttons on the board, and when the stimulator (visual auditory) appears, the player performs the duty assigned to him in the exercise according to the nature of the exercise program.
The device features:

Ease of manufacture.

.Suspense, excitement and exclusion from players get bored -

- The device can be formed in different ways and at different distances and as desired by the trainer. 
(IJRSSH) 2020, Vol. No. 10, Issue No. I, Jan-Mar

The possibility of involving more than one player in the exercise -

Availability of raw materials.

Medium cost.

.Easy to use -

:Determining the variables discussed

:Determination of the combined skill

At the request of the Scientific Committee ( $\square$ ), the field researcher's experience and taking the opinion of the supervisor, and after reviewing many previous sources and studies, and in order to determine the skill accurately, a questionnaire was distributed containing the most complex skills, which consists of two, three or four skills, For those with experience and specialization ( $\square \square$ ), to nominate the most frequent compound skill in the game and the reception skill (suppression) was the most recommended pass:

:Determine the appropriate test for the variable under study

:Determination of the skill test

After the compounding skill was determined by the experienced and specialized gentlemen, and after the researcher was informed of previous sources, researches and studies, and based on his field experience and the direction of the supervisor, the appropriate test for the combined skill was made, with some adjustments made to make it appropriate and consistent with the sample and the nature of the goals, and in the following the test used under consideration.

First: the name of the test: reception (suppression) and passing in two different directions (average)

The purpose of the test: - To measure the speed and accuracy of the reception (passing) skill and passing. Used equipments:

8(football balls) - leather tape measure - dust pigments (spray) - whistle number (1) - a length of (1) meters to determine the reception area (suppression) - a small goal number (2) (side length 60 x 60) Cm) - stop watch. Performance description:
e-ISSN: 2249-4642, p-ISSN: 2454-4671

The laboratory stands behind the line of the receiving area (suppression), which is 8 meters away from the provider (the dispatcher) on the right and left sides. After giving the starting signal, the provider passes the ball (ground) from the right side towards the reception area (suppression), the player advances into The receiving area (suppression) trying to receive the ball with any part of the foot and directing it towards the pass area, then passes the ball towards the goal (1), and in the second attempt it passes the ball to goal number (2) and so in succession of the goal (1) then (2), All testers perform the second four attempts, starting from the left side, in the same way as performances in pain Expectant mothers first four.

- Goal site No. (1) towards the right at an angle of (20) degrees with the horizontal line of the receiving area (suppression), and is a distance of (7) $\mathrm{m}$ from the receiving area.

- Goal site No. (2) towards the left at an angle of (20) degrees with the horizontal line of the receiving area (suppression), and it is a distance of (7) $\mathrm{m}$ from the receiving area.

Conditions of performance:

.The ball must be received within the specified reception area (suppression) -

- The test is performed by receiving the ball and passing towards the goal (1) then (2) then (1) then (2) according to the sequence.

Registration method:

.The laboratory is given (8) attempts by four attempts from each side -

.Calculated for the laboratory (one degree) for correct reception -

.For the laboratory (zero) is calculated for the wrong reception -

.Calculated for the laboratory (one score) for successful pass-

.For the laboratory (0) marks for the wrong pass -

\section{EXPLORATION EXPERIENCE:}

:The first exploratory experience

The researcher intended to conduct the exploratory experiment on (Friday) corresponding to (14-6-2019) at exactly $(5: 30)$ for the device designed (quality response) in the stadium (Specialized Center for Sports Talent Care - Al-Shaab Stadium Complex) on four players from the sample, As the experience was very 
useful and it was recognized through the validity of the use of the device, the mechanism of its operation, and the requirements it needs, as was the recognition of the efficiency of the auxiliary work team, and the development of the necessary solutions to the obstacles that faced the use of the device (delivery of electrical current - location and area - the process of organizing lamps - The arrangement of panels.

\section{:The Second Exploratory Experience}

The researcher intends to conduct the second exploratory experiment on Saturday (15-6-2019) at exactly (5:30) in order to codify the training program (for exercises) according to the level of maximum intensity for the players and the corresponding pulse, as the researcher determined to determine the maximum intensity and the level of pulse For players using the (POLAR H10) system, which is a standardized and internationally approved system used by European teams and clubs for severity technicians.

\section{:The Third Exploratory Experience}

The researcher intentionally conducted this experiment on Monday (17-6-2019) at exactly (5:30) at five players from the sample to find out the appropriateness of the composite skill test for the junior age group (14 years), as the exploratory experiment demonstrated the safety, efficiency and suitability of the test For the study sample after making some adjustments to it.

: The scientific basis

:Honesty (Validity)

The researcher intends to use the sincerity of the content or the content by relying on the opinions of professors and experts with expertise in the field of measurement and evaluation ( $\square$ ), as the test is considered true if it is presented to a group of specialists or experts in the field that the test measures and the judgment was that it measures what was set for it Adequacy ", and the researcher intends to find the validity coefficient for the complex skill test by Table No. (4)

Scientific foundations of the test (honesty, reliability, objectivity)

\begin{tabular}{|l|l|l|l|l|l|l|}
\hline indication & Objectivity & $\begin{array}{l}\text { Coefficient } \\
\text { of stability }\end{array}$ & Honesty & $\begin{array}{l}\text { measruing } \\
\text { unit }\end{array}$ & Candidate test & sequence \\
\hline Moral & 0.93 & 0.92 & 0.95 & $\begin{array}{l}\text { Minutes } \\
\text { second }\end{array}$ & $/ \begin{array}{l}\text { Reception } \\
\text { (suppression) and two- } \\
\text { way scrolling }\end{array}$ & 1 \\
\hline
\end{tabular}

adopting the self-honesty coefficient which is" the veracity of the experimental scores for the test in relation to the real scores that were obtained from the measurement errors, and self-honesty is measured by calculating the square root of the stability coefficient of the test " and as Shown in Table (4).

Coefficient of honesty $=$ coefficient of stability

:Reliability

Consistency is defined as "if a test was performed on a sample and then the test was repeated on the same sample, the results that appear the first time are consistency of the results that appear the second time" , and explains (Zakaria Muhammad Al-Zahir, et al. 2002). It is not fundamentally affected by re-testing and statistically treating through a correlation coefficient between the degrees of individuals for the various times of the test, and that the static test means that the test is reliable and reliable ", as the test and re-test method was used to find the coefficient of stability as the test was performed on ( 7) Players from the research community on (6-19) -2019), after which the tests were repeated after (7) days, then the results of the two tests were statistically treated using the simple correlation coefficient (Pearson) and Table (4) shows that.

:Objectivity

It means "the arbitrator's subjectivity does not interfere with his opinions and beliefs in the test results" , and although the candidate test was clear, understandable, and far from self-evaluation, as the examiner uses units of measurement (time - degrees of accuracy) to write down the results, in addition to that The assistant working group with specialists in physical education and sports science, the objective of the tests used was extracted by calculating the value of the simple correlation coefficient (Pearson) between the degrees of the first and second judgments, and after calculating the correlation coefficient of the tests, it was found that they have a high objective level and table (4) Clarifies that. 
Below the significance level (0.05)

\section{MAIN EXPERIENCE}

:Pre-test

The pre-test of the research sample for reception and passing skill was conducted on Saturday (7/7/2019) at $(5: 30 \mathrm{pm})$ at the stadium (Specialized Center for Sports Talent Care in the International People's Complex), and conditions related to the pre-test were fixed, such as time and place And the method of implementing the test and the assistant team for the purpose of controlling the variables that can affect the results during the conducting the post-tests.

:Special exercises

Exercises have been prepared using the quality response device whose main goal is to develop the speed and accuracy of the implementation of the combined reception and passing skill of the players of the research sample, as the researcher sought to be modern and varied performance and interesting and appropriate to the level of the study sample and implemented in a similar way to perform the skill in the game and the exercises moved away About the character of boredom and monotony followed by some coaches.

The independent variable (special exercises) was entered at the beginning of the main section (the first part) of the training unit, knowing that the total training unit time is (90) minutes. The exercises were applied to the experimental group by the auxiliary team and under the direct supervision of the researcher. As for the control group, its work was With the team coach in order to control all variables except for the independent variable, the duration of the exercises was limited to (30 - 40) minutes from the first part of the main section.

The intent of the researcher during the application of training exercises to the following criteria:
- The researcher used for the experimental group the training method by training (the high-intensity interval recursive) and adopted the (step-by-step) method to increase the intensity of the training to obtain adaptation and codified development in the dependent variables

- The intent of the researcher to use the intensity between $(80 \%-90 \%)$ for the high-intensity young training method and $(90 \%-100 \%)$ of the player's maximum for the repetitive training method.

- The polar H10 system was used to determine the levels of intensity and heart rate during effort and rest for each player and in each exercise.

Duration of training exercises (8) weeks.

.The number of training units is (24) training units -

- The training curriculum is divided into (3) training units per week, as the exercises are conducted with extreme intensity and less than maximum, so it requires adequate rest periods and full hospitalization for the players, and the sample is from the junior category (14 years).

Training days are (Saturday _ Monday _ Wednesday). :Post-test

After completing the application of all the special exercises prepared by the researcher to the experimental group, the researcher intentionally conducted the posttest of reception and passing skill on (....) on (14/9/2019), and the researcher emphasized the creation of all conditions and control of all exotic variables Which can affect the results of the study as in the pretest.

\section{:Statistical means}

The researcher used the statistical bag (SPSS) to extract and process the study results.

\section{RESULT AND DISCUSSION:}

Presenting and discussing the skill test results for the experimental and control groups:

1-1-4Presenting and discussing the pre- and post-skill test results for the experimental group:

Table (5) shows the results of the pre and post tests of the reception and passing skill of the experimental group 
Table (5)

Shows the difference between the arithmetic mean, the standard deviations $(\mathrm{P})$ and $(\mathrm{PH})$, and the rate of development of the test results for the tribal and dimensional reception and passing skill

\begin{tabular}{|c|c|c|c|c|c|c|c|c|c|c|}
\hline \multirow{2}{*}{$\begin{array}{l}\text { Indicati } \\
\text { on of } \\
\text { differen } \\
\text { ces }\end{array}$} & \multirow{2}{*}{$\begin{array}{l}\text { Evoluti } \\
\text { on rate }\end{array}$} & \multirow{2}{*}{$\begin{array}{l}\text { Signific } \\
\text { ant } \\
\text { level of } \\
\text { SIg }\end{array}$} & \multirow{2}{*}{$\begin{array}{l}\text { The } \\
\text { standard } \\
\text { deviatio } \\
\mathrm{n} \text { of the } \\
\text { differenc } \\
\text { e e }\end{array}$} & \multirow{2}{*}{$\begin{array}{l}\text { Media } \\
\text { teams }\end{array}$} & \multicolumn{2}{|c|}{ Dimensional test } & \multicolumn{2}{|c|}{ Tribal test } & \multirow{2}{*}{$\begin{array}{l}\text { measruin } \\
\text { g unit }\end{array}$} & \multirow{2}{*}{$\begin{array}{l}\text { Statistical } \\
\text { treatments }\end{array}$} \\
\hline & & & & & $\begin{array}{l}\text { standar } \\
d \\
\text { deviati } \\
\text { on }\end{array}$ & $\begin{array}{l}\text { Arithmet } \\
\text { ic mean }\end{array}$ & $\begin{array}{l}\text { standar } \\
\mathrm{d} \\
\text { deviati } \\
\text { on }\end{array}$ & $\begin{array}{l}\text { Arith } \\
\text { metic } \\
\text { mean }\end{array}$ & & \\
\hline Moral & & 0.000 & 0.042 & 0.732 & 0.120 & 1.188 & 0.0382 & 0.456 & $\begin{array}{l}\text { Minutes / } \\
\text { second }\end{array}$ & $\begin{array}{l}\text { Reception and } \\
\text { pass }\end{array}$ \\
\hline
\end{tabular}

$\mathrm{N}=(10)$ under the significance level ((0.05 and 9 degrees freedom))

By presenting the pre- and post-test results for the skill search variable (reception and pass) for the experimental group shown in Table (5), which indicates that there is a significant difference between the results of the two tests and in favor of the post-test.

The researcher attributes the development of the experimental group in the results of the post-skill test is the result of using special exercises according to the use of the modern and advanced electronic quality system within a codified and studied scientific training program and in the way that serves the development of research variables, so any training curriculum does not depend on scientific planning not It can lead to the desired results from it, so the technical staff must possess scientific knowledge in addition to field experience because most trainers with scientific and practical experience "are the only ones who find solutions that are semi-exemplary when building the structure of the training process" and etc. Matters related to the planning's share of the work of training and dealing with distress.

Also, the quality of the special exercises included in the training curriculum prepared by the researcher was effective for developing the skill performance of the sample under study, as it was prepared in a manner that is consistent with the nature and requirements of the modern football game, as modern exercises were used in a different way that serves more than one goal It differs completely from the nature of performing the exercises followed, using the method of combining more than one skill such as linking the reception skill (suppression) and passing. It is one of the complex skills that are in line with what is happening in the game, as it is rare for the player to perform a basic basic skill, such as reception only, rolling or changing. Aim, according to the use of the designed quality response device because complex exercises are considered "a form of sports training through which the linking of the components of different training cases can be carried out, which speeds up the suitability of physical and technical variables to suit the requirements of competitions, as well as helps to overcome the fear factor The sense of trust and elimination of hesitation in competition "(), and because the use of electronic devices has a great importance in the process of training and raising the level of players, and this is what (Kamal Jamil Al-Rabadi, 2004) indicated that ignoring sports technology leads to the backward of the athlete, so we have to take care of exploiting Tesn All modern sports equipment, tools and means for the development and improvement of achievement."

Presenting and discussing the results of the pre- and post-skill test of the control group: 
Table (6) shows the results of the pre- and post-test of the reception and passing skill of the control group Table (6)

Shows the difference between the arithmetic mean, the standard deviations, $(\mathrm{F})$ and $(\mathrm{FH})$ for the differences, the significance value, and the evolution rate for the pre-test and dimensional skill test results

\begin{tabular}{|c|c|c|c|c|c|c|c|c|c|c|}
\hline \multirow{2}{*}{$\begin{array}{l}\text { Indicatio } \\
n \quad \text { of } \\
\text { differenc } \\
\text { es }\end{array}$} & \multirow{2}{*}{$\begin{array}{l}\text { Evoluti } \\
\text { on rate }\end{array}$} & \multirow{2}{*}{$\begin{array}{l}\text { Signif } \\
\text { icant } \\
\text { level } \\
\text { of SIg }\end{array}$} & \multirow{2}{*}{$\begin{array}{l}\text { The standard } \\
\text { deviation of } \\
\text { the } \\
\text { difference e }\end{array}$} & \multirow{2}{*}{$\begin{array}{l}\text { Media } \\
\text { teams }\end{array}$} & \multicolumn{2}{|c|}{ Dimensional test } & \multicolumn{2}{|c|}{ Tribal test } & \multirow{2}{*}{$\begin{array}{l}\text { measuri } \\
\text { ng unit }\end{array}$} & \multirow{2}{*}{$\begin{array}{l}\text { Statistical } \\
\text { treatments }\end{array}$} \\
\hline & & & & & $\begin{array}{l}\text { standar } \\
\mathrm{d} \\
\text { deviati } \\
\text { on }\end{array}$ & $\begin{array}{l}\text { Arithmet } \\
\text { ic mean }\end{array}$ & $\begin{array}{l}\text { standar } \\
\mathrm{d} \\
\text { deviati } \\
\text { on }\end{array}$ & $\begin{array}{l}\text { Arithm } \\
\text { etic } \\
\text { mean }\end{array}$ & & \\
\hline Moral & & 0.001 & 0.027 & 0.128 & 0.066 & 0.602 & 0.041 & 0.473 & $\begin{array}{l}\text { Minutes } \\
\text { / second }\end{array}$ & $\begin{array}{l}\text { Reception } \\
\text { and pass }\end{array}$ \\
\hline
\end{tabular}

$\mathrm{N}=10$ below the significance level of 0.05 and at freedom 9

By presenting the results of the pre- and post-test for the skill search variable (reception and passing) of the control group and shown in Table (6), the table indicates that there are significant differences in the results of the combined skill between the results of the pre- and post-tests in favor of the post-test, as the development of the control group was not at the level Required compared to the experimental group.

The researcher attributes the reason for this development to the members of the control group that came logically in order for the commitment of the training units, by four units per week, and within the curriculum prepared by the ministry that the center belongs to the Ministry of Youth and Sports and the player is obliged to attend, which helps the players to increase their sensitivity to the ball and their awareness of the situation and thus develops Skillful performance, and this is consistent with what (Mufti Ibrahim) mentioned when he sees "" that repeating the exercise in the training units makes the player less error and makes it more controlled by it as a natural result of increasing the player's sense of the ball, which makes him take the appropriate and correct position to perform the Skill and avoid mistakes that occur, as it earn him a good compatibility to perform the skills."

Presenting and discussing the dimensional skill test results for the experimental and control groups:

After the researcher finished presenting the results of the tribal and posttest skill tests for the two research groups (experimental and control) and discussing them, he deliberately presented the results of the posttest tests for the two groups and discussed them to show the level of the effect of the independent variable on both groups, as shown in Table (7)

\section{Table (7)}

Shows the arithmetic mean, the standard deviations, and the tabular value (T) calculated in the dimensional skill tests of the two groups in question

\begin{tabular}{|c|c|c|c|c|c|c|c|c|}
\hline Indication & Sig & Calculat & Control gr & & Experime & group & measuri & \\
\hline & & & $\begin{array}{l}\text { standard } \\
\text { deviation }\end{array}$ & $\begin{array}{l}\text { Arithmetic } \\
\text { mean }\end{array}$ & $\begin{array}{l}\text { standard } \\
\text { deviation }\end{array}$ & $\begin{array}{l}\text { Arithmetic } \\
\text { mean }\end{array}$ & & treatments \\
\hline Moral & 0.000 & 13.481 & 0.066 & 0.602 & 0.120 & 1.188 & $\begin{array}{l}\text { Minutes } \\
\text { / second }\end{array}$ & Reception and pass \\
\hline
\end{tabular}


(*)Degree of freedom = 18 significance level 0.05 By presenting the results of the dimensional test of the skill search variable (reception and passing) for the experimental and control groups, which are shown in Table (7), as the table showed that there are significant differences with statistical significance in favor of the experimental group.

The researcher attributes the preference to the experimental group in the results of the post-test is the result of the use of special exercises and according to the use of a quality response device designed in a scientific manner carefully and carefully approached in terms of codifying the training program and its vocabulary, which helped in the implementation of the set plan and thus achieving the goals during the period Time to implement the program, as "the scientific training curricula are considered the correct basis that leads to the training process to achieve the goals set and help in reaching high levels. "

Also, the reason for the evolution of the experimental group at the expense of the control group for the diversity and effectiveness of the special exercises prepared by the researcher using two quality response devices and their ability to excite the potentials of the players by increasing suspense and excitement and motivating them to make exceptional efforts and challenge the boredom that accompanies the use of the exercises followed, and this is what was done It was confirmed by (Ahmed Amin Fawzi, 2008), as he stated, "The diversity of tools and their exercises will excite players and increase the motivation towards the advancement and advancement of the athletic level." For him, it is also known that the young player gets bored quickly compared to the advanced player, therefore, that the use of a large number of exercises and tools in the training unit is not only for the purpose of achieving development goals, but also is used in order for the young person not to get bored."

Also, what distinguishes the program prepared by the researcher is that he is a specialist and is able to accommodate the situation of the players and determine what would serve the player and contribute significantly to development and skill access to mastery and implementation with the necessary speed and accuracy. He put various modern exercises in a technical way in which a lot of creativity simulates the reality of the game and leads Differently and differently, and this is consistent with what he mentioned (Mohamed Reda Ibrahim) requires the coach to be a very understanding creative, he has a large storehouse of various exercises that allow him to change the state of boredom and boredom periodically, as the coach can enrich the skills and exercises by adopting an effective $\mathrm{T}$ artistic models show similar exercise movements that develop motor abilities required for the game.

\section{CONCLUSIONS:}

In light of the research objectives and the test results that were reached in the pre and post tests, the researcher shows the following conclusions:

- The exercises for using the designed QUALITY RESPONSE have effective and positive impact on developing the speed and accuracy of reception and passing skill performance.

- The amendment that the researcher made to the skill test made it more suitable for the researched variable under study, and he took into account the capabilities of the sample.

\section{ENDORSEMENT:}

In light of the researcher's findings, he recommends the following:

- The use of the (QUALITY RESPONSE) device designed to train and develop the speed and accuracy of basic and complex skills, as it has proven its worth in developing the speed and accuracy of reception and passing skill, provided that the performance is associated with movement and is similar to the conditions of the match.

- The need to include electronic devices in the training process and take advantage of the characteristics and advantages that are distinguished for the development of the physical, skill, planning and psychological aspect, because development has become a necessary need in order to continue towards achieving positive results.

- Choosing the quality of coaches, especially to supervise the players of the Sunni stages, who have the competence and the scientific knowledge are able to prepare codified training curricula that contribute to developing their abilities and capabilities. 
- Carrying out similar studies on different age groups, and different physical and motor abilities using devices.

\section{REFERENCES:}

- Ahmad Amin Fawzi: Psychology of youth training sports, 2nd edition (Cairo, Dar Al Fikr Al Arabi, 2008).

-- Ahmad Farhan Ali Al-Tamimi: Fundamentals of Scientific Research and Statistics in Physical Education, First Edition, (Najaf Al-Ashraf, Dar Al-Diaa for Printing, 2015).

- Thamer Mohsen (and others); football testing and analysis: (Mosul, Mosul University Press, 1991 AD).

- Thamer Mohsen and Sami Al-Saffar: Fundamentals of Training in Football (Baghdad, Dar Al-Kutub Press, 1988).

- Hussein Ali Al-Ali and Amer Fakher Shaghati: rules for planning sports training, training departments training for highlands, (Baghdad, Al-Karar Printing Office, 20060.

- Zakaria Muhammad Al-Zahir (and others): Principles of Measurement and Evaluation in Education, 1st edition: (Amman, The International Scientific House for Publishing and Distribution and the House of Culture and Publishing, 2002 AD).

- Al-ZuwaidHisham and (others). Principles of Measurement and Evaluation in Education, 2nd edition, (Amman: Dar Al Kutub for Printing, Publishing and Distribution, 1998).

- Abdullah Al-Kandari and Muhammad Ahmad: Methods of Scientific Research in Physical Education and Islamic Sciences, 1st edition: (Kuwait, Al-Falah Library for Publishing and Distribution, 1999 AD).

- Abdullah Hussein Al-Lami: The Scientific Bases in Athletic Training, (Amman, Al-Taif for Printing, 2004 $\mathrm{AD})$.

- Kamal Jamil Al-Rabadi: Athletic Training (for the twenty-first century), 2nd edition, (Amman, Wael Publishing House, 2004 AD).

- Mohamed Reda Ibrahim: Field application of theories and methods of sports training, 2nd floor, (Baghdad, University House for Printing, Publishing and Translation, 2009).

- Mustafa Hussein Bahi: Scientific Transactions between Theory and Practice, Persistence, Truthfulness, Objectivity - Standards: (Cairo, The Book Center for Publishing, 1999 AD).
- Mufti Ibrahim: The comprehensive reference in football, 1st edition (Cairo, Dar Al-Kitab Al-Hadith, 2010).

- WajihMahjoub: Principles and Methods of Scientific Research, 1st floor, (Amman, Dar Al-Manhajj Publishing and Distribution, 2001). 